\title{
THE EFFECTS OF WEATHER CONDITIONS ON THE HEALTH OF PEOPLE LIVING IN URBAN AND RURAL ENVIRONMENTS
}

\author{
Irena Čelićl, Sandra Živanovićn ${ }^{2}$ Nebojša Pavlović3 \\ *Corresponding author E-mail: irena.celic994@gmail.com
}

A R T I C L E I N F O
Original Article
Received: 25 September 2018
Accepted: 28 December 2018
doi:10.5937/ekoPolj1901063C
UDC 613.11:[911.373+911.375

Keywords:

weather conditions, people's health, urban and rural environment

JEL:I12

\section{A B S T R A C T}

Meteorology is an essential part of people's lives. Its influence on every aspect of human life is vast and especially connected to the well-being of an individual. The objective of this paper is to ascertain how meteorologic changes influence the health of people who live in urban and rural environments. The testing was carried out on a sample of 130 respondents. The respondents are of different sex, age and come from various environments. This research was conducted via an anonymous questionnaire. The results point to the fact that meteorological changes affect the health and well-being of both healthy and ill individuals, whether they live in urban or rural environments. The significance of this paper is reflected in the acquiring of data that can be used in medicine as well as health tourism.

(C) 2019 EA. All rights reserved.

\section{Introduction}

Health is the most valuable thing a person can have. Due to increasingly faster pasted lifestyles, very few people take care of their physical and mental health. This type of lifestyle can lead to more and more people being prone to different illnesses.

There is a many factor with negatively effects on people's health. Genetics and unhealthy lifestyles aside, certain global changes that have an influence on both healthy people and those who have chronic illnesses, are nowadays considered a significant health risk factor. Climate change and unstable weather conditions are identified as the biggest global changes. Data that is gathered from biometeorological weather forecasts is invaluable for

1 Irena Čelić, PhD Student, Faculty of Hotel Management and Tourism in Vrnjaĉka Banja University of Kragujevac, Vojvođanska 5A, 36210 Vrnjackka Banja, (+381 36) 51500 21, e-mail: irena.celic994@gmail.com, ORCID ID (https://orcid.org/0000-0001-6914-6321)

2 Sandra Živanović, PhD, Associate Professor, Faculty of Hotel Management and Tourism in Vrnjaĉka Banja - University of Kragujevac, Vojvođanska 5A, 36210 Vrnjaĉka Banja, (+381 36) 51500 21, e-mail: zivanovicsandra@hotmail.com, ORCID ID (https://orcid.org/00000002-9149-4530)

3 Nebojša Pavlović, PhD, Associate Professor, Faculty of Hotel Management and Tourism in Vrnjaĉka Banja - University of Kragujevac, Vojvođanska 5A, 36210 Vrnjackka Banja, (+381 36) 51500 21, e-mail: racapn@gmail.com, ORCID ID (https://orcid.org/0000-0002-3981-7945) 
those who are more susceptible to the influence of changing weather conditions. This means that people who have difficulties tolerating temperature differences can be better prepared with the proper therapy and be able to reduce the negative effects to a minimum. Likewise, health-warning systems that exist in big cities in the USA are very helpful. These warning systems are based on a synoptic approach and forecasting meteorological variables that can predict dangerous weather conditions and warn their citizens (Ballester, 2003). The benefits of this research are pertaining to the possibilities of educating people about the influence of weather conditions on health and promoting a healthy lifestyle that people disregard nowadays, especially in urban environments.

The issue of this research is establishing the effects that weather conditions have on people's health in urban and rural environments. The objective of this paper is to ascertain how meteorologic changes influence the health of people who live in urban and rural environments. The main goal of this paper is to establish the effect of changing weather conditions on health of people who live in different environments.

\section{Meteorology as a science}

During the years, environmenatl's process and phenomena have negatively effects on people. Meteorology, as a branch of geophysics, studies these different processes in detail. As a science, meteorology has been developing for a long time. The Greeks were the first to record meteorological observations (Neves, Gallardo \& Vecchia, 2017).

Meteorology is a science that deals with atmospheric changes (Vujević, 1948). Meteorology is a science that studies different physical processes that take place in the atmosphere and how they interact with land and sea surfaces (Todorović, 2012). Physical processes and phenomena have a mutual term "weather". Weather is the atmospheric state in a certain location at a certain time (Kaiser, 2003). Weather is the state of meteorological elements and phenomena that occur in the lowest layers of the atmosphere in a short period, in a certain geographic area. It often changes and is determined by meteorological elements and processes (Živanović, 2015).

During historic development, scientists have divided meteorology into a series of subgroups, such as synoptic meteorology, dynamic meteorology, aerology, climatology, micrometeorology and others (Deljanić, 1976; Živanović, 2015). From a medical standpoint, synoptic meteorology is important as it provides predictions of weather conditions, and based on those, advice and instructions are given to those with chronic illnesses but to those who are healthy, on how to behave in situations when weather conditions change rapidly (Gajić, 2013).

\section{Meteorological elements and phenomena}

A large number of factors can affect the weather and weather conditions at a certain location. We can call all of these factors by a single name - meteorological elements and phenomena. Meteorological elements consist of a number of parameters that are used in meteorology to determine quantitative and qualitative properties of the atmosphere (Cvetanović and associates, 1988). 
Cvetanovic and associates (1988) list temperature and air humidity, atmospheric pressure, cloudiness and other occurrences as meteorological elements. According to Zivanovic (2015), meteorological elements include Sun radiation, the Earth's radiation, horizontal visibility, temperature, barometric pressure, air flow, precipitation, the height of snow accumulation, while meteorological phenomena include fog, clouds, snow, frost, hoar frost, black ice, cyclones, anticyclones, air fronts and atmospheric storms (Živanović, 2015).

\section{The effects of weather conditions on health}

Biometeorology is the study of the effect of weather on all living things. Biometeorology makes up a large part of meteorology. It is a science of relationship between atmosphere physical and chemical factors and living organisms (Kukutanov, 2014). Humane biometeorology studies the effects of weather on people's health through various fields, according to Zivanovic (2015). According to the area it studies, humane biometeorology can be divided into meteorophysiology, meteoropathology, meteorotherapy and meteoroprophylaxis (Živanović, 2015).

Weather conditions affect all areas of human life. Some of these areas include food manufacturing, transport, tourism, construction, foresting and so on. As an example, food manufacturing will depend on weather conditions at a certain location. A smaller amount of precipitation during a warm period can influence the loss of crops because of drought (Otorepec, 1991). Weather conditions also have a large influence on health. Health is the level of functional and metabolic efficiency of a living organism. In people, it is the ability to adapt to and be in control of one's self when confronting physical, psychological, emotional or social changes in their environment, whether as an individual or as a community (Huber et al, 2011). Changes of meteorological factors, such as Sun radiation, temperature, humidity or rain can have an effect on the environment, as well as the person. Aside from having an influence on the health of the individual, weather conditions also, affect mood, behaviour and the general state of the organism (Živanović \& Manojlović, 2016).

Weather conditions can be classified in multiple ways. The methods for classification are divided into two groups: the subjective (manual) and objective (automatic) (Putniković, 2017). Weather conditions can be divided into three groups: weather conditions of the warmer period of the year (weather without frost), weather conditions where the highest temperature is positive and the lowest is negative and the weather conditions of the colder period of the year (weather with frost) (Živanović, 2015).

\section{Meteoropathy - the illness of the modern age}

The human organism was created in a way that it is able to adjust to different influences from nature. The intensity of a person's reaction to weather changes can be different (Brkić, 2006). Certain organisms adjust faster and with more ease to these influences, while others can be very sensitive (Živanović, 2015). One of the illnesses that develops 
under the influence of weather elements and conditions is meteoropathy. The term meteoropathy dates back to the ancient states. The fact that term meteoropathy comes from the Greek words meteoron (heavenly apparition) and pathos (pain, suffering), reflects this statement.

Weather related pains could be of different intensities and have a common term, meteoropathy. Meteoropathy is an illness of the modern age. It refers to the difficulties of a neurovegetative nature that can happen in certain weather conditions. People who are susceptible to the effect of weather changes are meteoropathic (Živanović, 2015).

Changes in temperatures, air humidity and atmospheric pressure can cause headaches and rheumatic pains (Kaiser, 2003). Foggy weather, when the air humidity is high, can lead to difficulties in breathing, even in healthy individuals (Dukić, 1967).

Environmental temperature changes are one of the most significant indicators of climate change that can not only lead to death and illness, but also cause major problems to those who suffer from cardiovascular and respiratory illnesses (Zheng et al, 2016). High temperatures can lead to exhaustion (Kaiser, 2003). Due to sudden increases in temperature (especially during the summer months), the blood vessels in humans can expand and that can lead to a drop in blood pressure (Živanović, 2015). Because of these natural elements, those who suffer from high blood pressure, despite of medication, might suffer of the disease.

Furthermore, low temperatures can have an even worse effect on people who suffer from chronic cardiac pains. Blood pressure increases during warm weather (Zuzelo, 2018). Low temperatures can make the blood vessels narrower, putting a bigger strain on the heart. In a matter of just 2 or 3 days, a person who has blood pressure problems can have a heart attack with fatal consequences (Eckmann et al, 2000). Types of people who are usually influenced by high air temperatures are children, the elderly, obese and sick people (Kaiser, 2003).

Atmospheric pressure can also make an impact on a person. High atmospheric pressure can slow down breathing, while low atmospheric pressure can have a negative effect on patients with cardiac and rheumatic issues.

As previously mentioned, the effects that weather conditions have on health can be of different intensities. This means that changes of certain meteorological elements can cause various problems in people. Zivanovic (2015) states that these problems can be psychological in nature (fatigue, sudden mood swings, insomnia), physical problems (headache, migraine, mood swings), cardiovascular issues (increased heart rate, spikes in blood pressure) or problems with the digestive tract (gastritis, stomachaches). A sudden weather change can lead an increased number of heart attacks and strokes, pneumonias and asthma attacks in older generations and in patients with chronic cardiovascular problems (Živanović, 2015). 


\section{A representation of weather influences on certain illnesses}

Weather conditions can have a different impact on people who live in urban and rural environments. Weather changes can have an effect on people with certain health issues (Horowitz, 2002). Brain cells, the cardiovascular system, rheumatological disorders and others can be especially affected by weather changes.

Psychological disorders. The most common form of these disorders is insomnia. Insomnia is the feeling of inadequate sleep, regarding either quality or quantity of it, most commonly not connected to sleep in the afternoon hours (Andreoli, Loscalzo \& Carpenter, 2008). A sleeping disorder can lead to numerous problems, such as parasomnia and narcolepsy. Psychosis that can lead to suicide occurs as a more severe form of mental illness, and is usually associated with sudden changes of hot and cold weather or warm wind (Andreoli, Loscalzo \& Carpenter, 2008).

General physical disorders. These types of disorders are becoming more and more common nowadays. Headaches can be a manifestation of these types of disorders. They are described as a painfully sensitive neurological structure in a person. High temperatures, wind or low air humidity can be common causes (Andreoli, Loscalzo \& Carpenter, 2008).

Disorders of the gastrointestinal tract. A large number of people is troubled by these disorders, and the most common form is gastritis. Gastritis is an inflammation of gastric mucosa. Patients with gastritis are usually the most sensitive in spring, when the air temperature induces acid secretion. In spring, stomach acid secrets more, which can cause increased pains (Andreoli, Loscalzo \& Carpenter, 2008).

Rheumatic disorders. One of the most common rheumatic disorders is arthritis. A disease that manifests itself with pain and rigidness of joints is called arthritis. Sudden changes of atmospheric pressure and humidity can lead to an increased feeling of pain in patients with arthritis, while lower temperatures increase rigidness. A drop in the atmospheric pressure causes the spreading of fluids and gases, including synovial fluids and the air inside the synovial membrane, which can cause pressure to the tissue that, is inflamed or injured, increasing pain levels (Bevan, 1987). Dampness and cold weather can especially affect rheumatic illnesses and cause arthritis to appear (Cvetanović \& associates, 1998).

Cerebrovascular disorders. These types of disorders are not seasonal. They most commonly manifest as trombosis, apoplexy and emboly. Cardiovascular disorders can appear at any time of the year. Most commonly, they manifest during sudden drops in atmospheric pressure, due to wind and cloudiness, as well as a rise in temperature (Cvetanović \& associates, 1998).

Bronchial asthma. Asthma is an illness that is characterized by difficulty in breathing due to the narrowing of airways and reduced airflow. For the past twenty years, asthma has been one of the leading disease of respiratory organs (Cucalon, 1985). An increase in air humidity, low cloudiness or a drop in temperature can all have negative effects on patients with asthma (Cvetanović \& associates, 1998). 
Hypertension (elevated blood pressure). Hypertension affects nearly 50 million people in the USA, which makes it a bigger threat than any cardiovascular disease (Sacks et al, 2001). Combined with other disorders it poses a risk factor for developing angina pectoris or having a heart attack. The changes are most apparent when the temperature and the atmospheric pressure drop (Bevan, 1987). This puts people with an elevated blood pressure at higher risk during the cold part of the year. According to the World Health Organization (WHO), the deadliest diseases in 2016 were diseases of the heart (http://www.who.int). This statement is precisely the reason why there needs to be a bigger focus on the influence of weather on health, because different weather conditions can lead to hypertension, which can cause death.

\section{The research methodology}

In accordance with the theme of the paper, in this chapter we will set the topic, objective and hypothesis of the research as well as describe the methodology used for obtaining data. The research itself was conducted on sample of 78 respondents who live in urban environments, during December of 2017. The sample of respondents who live in rural environments consists of 52 people questioned during April of 2018.

The topic of research. The topic of this research is to determine the effects that changes of meteorological conditions and phenomena have on people's health. The significance of this research is best seen in gathering newer data that can be used in both medicine and health tourism.

The objective of research. The main objective of this paper is to ascertain the influence weather changes have on people who live in different environments. In accordance with the objective, the effect of weather on both healthy and ill individuals will be shown, as well as the most common issues people face because of sudden weather changes.

The hypothesis of research. Based on the set objective, which refers to determining the effect of weather changes, the main hypothesis is defined. The hypothesis: The changes of weather conditions in urban and rural environments have an effect on a person's health. Based on the main hypothesis, the following is defined: Hypothesis number 1: The weather changes in urban and rural environments affect healthy people. Hypothesis number 2: The weather changes in urban and rural environments affect healthy people with certain diagnoses. Hypothesis number 3: Weather conditions and phenomena have a different effect on people in urban and rural environments.

The methodology of research. For the purposes of this research, methods such as descriptive analysis, statistical analysis and a survey questionnaire were used. The method of a survey questionnaire was applied to research the problem and to achieve the set objectives. The technique that was used during the questionnaire examination was a survey questionnaire that was specifically tailored for the purpose of the research and consists of 17 questions. The questions were divided into two groups. The first group of questions are general information about the respondents (age, sex, education, and employment status), while the second group of questions refers to the respondents' 
health and weather conditions affect their health. The majority of the questions that the respondents had to answer were closed type questions, meaning they could be answered with more than one option. For a total of 13 questions, the respondents had the option of choosing one out of multiple answers provided, 1 question required two answers, while the Likert scale was used on 2 questions, where the respondents had to rate a statement from 1 to 5, depending on how strongly they agreed or disagreed with it. The survey contained one open type question, where the respondents had to write down a complete answer.

\section{Results}

The total number of respondents that participated in the research was 130 . Out of those 130, 78 respondents live in urban environments, while 52 live in rural ones. The majority of the respondents were female. The bigger part of the respondents that live in urban environments were over the age of fifty, while the ones that live in rural environments are between 25 and 49 years of age. Relating to the total number of participants, the respondents who have completed high school and are unemployed are prevalent.

The opinions on the condition of their health are vastly diverse. According to the data from Table 1, we can conclude that the people who live in urban environments consider themselves to be extremely healthy, while those in rural environments believe they are fairly healthy.

Table 1. The opinions of the respondents on their own health

\begin{tabular}{|l|r|r|}
\hline \multicolumn{1}{|c|}{ Offered answers } & Urban environment & \multicolumn{1}{c|}{ Rural environment } \\
\hline Extremely healthy & 33 & 9 \\
\hline Fairly healthy & 16 & 28 \\
\hline Unhealthy & 29 & 15 \\
\hline Total & 78 & 52 \\
\hline
\end{tabular}

Source: Self-conducted research

Weather changes influence people whether they live in an urban or rural environment. Even 65 respondents answered that weather changes influenced their health. Out of the rest 130 respondents, 30 of those said that weather changes did not influence their health while 35 stated that it affected them occasionally. Observing the areas where the respondents are from, over half of those surveyed in the rural environment said that weather changes affect their health.

The respondents rated their health based on different criteria that relate to their mood, occurrence of headaches or pain in places where they had fractured bones, during a cloudy or rainy day. When it comes to their mood, data from Table 2 reflects that the rating is lower during cloudy or rainy days in urban environments, while it is 1,4 higher in rural environments. If the entire sample is observed, it can be deduced that the average rating of mood in the respondents is 2,74 . 
Table 2. The mood of the respondents during a cloudy and rainy day

\begin{tabular}{|l|r|r|r|r|}
\hline & \multicolumn{1}{|c|}{$\begin{array}{c}\text { Number of } \\
\text { respondents }\end{array}$} & $\begin{array}{c}\text { Lowest rating } \\
\text { (very bad) }\end{array}$ & $\begin{array}{c}\text { Highest rating } \\
\text { (excellent) }\end{array}$ & Average rating \\
\hline Urban environment & 78 & 1 & 5 & 2,04 \\
\hline Rural environment & 52 & 1 & 5 & 3,44 \\
\hline
\end{tabular}

Source: Self-conducted research

A rainy day can often cause headaches. The majority of respondents from rural environments have stated that they get headaches during rainy or cloudy days; while the population from the urban environment answered, they sometimes have headaches during this type of weather. When it comes to pain in fractured areas, the results point to the fact that most of the respondents who have had fractures feel pain in those areas during a rainy day. Out of the entire sample, 93 have never had a fracture; while only 13 respondents who have had fractures stated they never feel pain on rainy or cloudy days.

When it comes to fog, the breathing of respondents in rural environments is usually obstructed, while those in urban environments report that their breathing is only occasionally obstructed. Figure 1 shows the structure of answers when it comes to difficulties in breathing on days with fog.

Figure 1. Breathing of respondents during fog

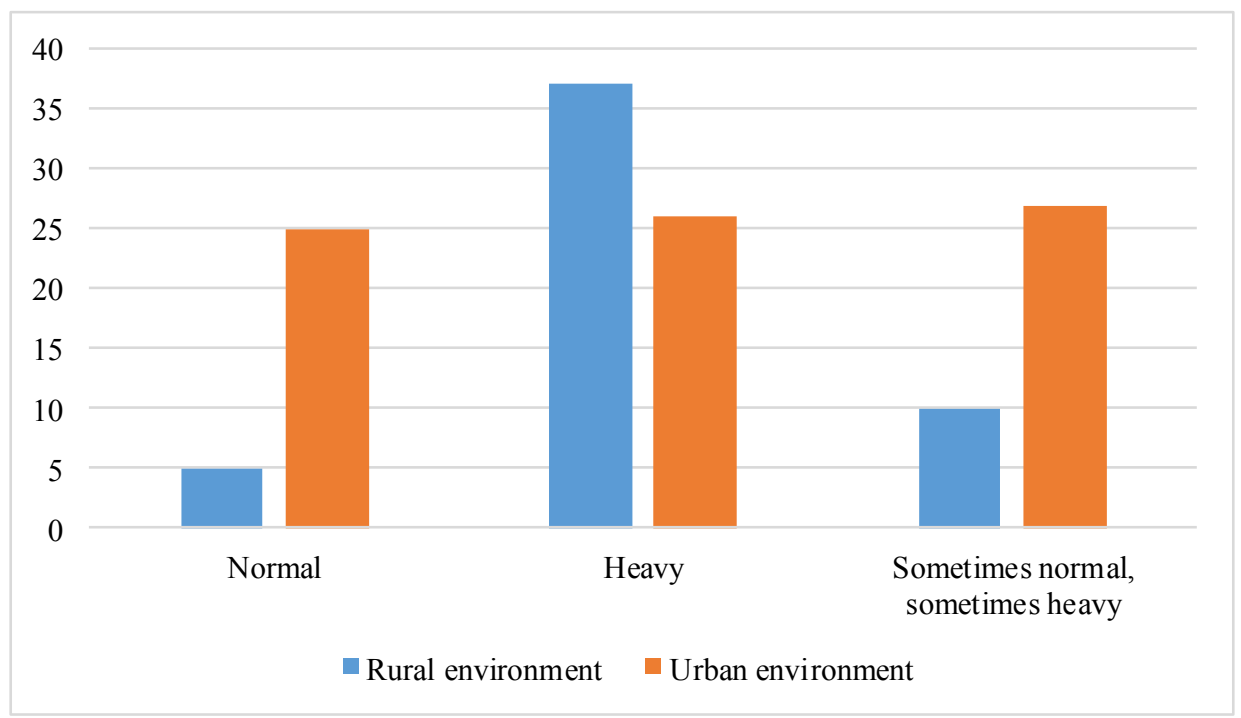

\section{Source: Self-conducted research}

Blood pressure of most respondents in both urban and rural environments remains mostly stable during the winter months of cold weather. The majority of the ones that were interviewed, 64 to be exact, has had a problem with increased blood pressure during 
winter months, while only 3 of them had lower blood pressure. Even 61 respondents reported that they have stable blood pressure during these months.

Weather conditions have a strong impact on those who have chronic illnesses. In rural environments, 15 respondents suffer from some type of chronic illness, while that number reaches 30 in urban environments. Based on the data from Table 3, it can be concluded that people in rural environments mostly suffer from cholesterol issues, while the ones that live in the urban environments have issues with high blood pressure.

Table 3. Most common chronic illness in respondents

\begin{tabular}{|l|r|r|}
\hline & \multicolumn{2}{|c|}{ Number of respondents } \\
\hline \multicolumn{1}{|c|}{ Chronic illness } & Urban environment & Rural environment \\
\hline High blood pressure & 9 & 4 \\
\hline Bronchitis & 3 & $/$ \\
\hline Low blood pressure & 3 & $/$ \\
\hline Allergy & 2 & 1 \\
\hline Diabetes & 4 & 1 \\
\hline Rheumatism & 5 & $/$ \\
\hline Thyroid gland & 4 & 9 \\
\hline Cholesterol & $/$ & \\
\hline
\end{tabular}

Source: Self-conducted research

Most of the respondents questioned stated that they were not on therapy prescribed to them by a medical specialist. The others that are receiving treatment said that their condition would worsen if the weather conditions changed and they had not taken their medication on time. If change in the atmospheric pressure occurs, most respondents from urban environments said that their health sometimes changed, while the other respondents stated that it most commonly did not change at all.

High temperatures during summer months are conducive to forming certain illnesses. The reported health of respondents was significantly lower during these months, as shown in Table 4. The average rating of health during summer months is 2,39 (urban environment 2,32 ; rural 2,46 ).

Table 4. Respondents' health during summer months

\begin{tabular}{|l|r|r|r|r|}
\hline & \multicolumn{1}{|c|}{$\begin{array}{c}\text { Number of } \\
\text { respondents }\end{array}$} & Lowest rating & Highest rating & Average rating \\
\hline $\begin{array}{l}\text { Urban } \\
\text { environment }\end{array}$ & 78 & 1 & 5 & 2,32 \\
\hline $\begin{array}{l}\text { Rural } \\
\text { environment }\end{array}$ & 52 & 1 & 5 & 2,46 \\
\hline
\end{tabular}

Source: Self-conducted research

There are different factors that lead to health deterioration. Foggy weather and temperature fluctuations have the biggest influence on people in rural environments, 
while the ones living in more urban parts find that the biggest problems are weather fluctuation and high air humidity. The respondents had to choose two answers. These results are represented in Table 5.

Table 5. Influence of certain meteorological elements and phenomena on health in respondents

\begin{tabular}{|l|r|r|}
\hline \multirow{2}{*}{ Weather conditions and phenomena } & \multicolumn{2}{|c|}{ Number of respondents } \\
\cline { 2 - 3 } & Urban environment & \multicolumn{1}{c|}{ Rural environment } \\
\hline 1-Rain & 15 & 12 \\
\hline 2-Fog & 18 & 40 \\
\hline 3-Cloudiness & 14 & 8 \\
\hline 4-Drastic temperature fluctuations & 45 & 16 \\
\hline 5-High air humidity & 38 & 10 \\
\hline 6-Wind & 15 & 12 \\
\hline 7-Atmospheric storms & 13 & 6 \\
\hline
\end{tabular}

Source: Self-conducted research

\section{Discussions}

The results of this research point to the fact that weather changes affect people that live both in urban and rural environments. People from urban environments are especially affected by high temperature fluctuations and high air humidity, while the ones from rural environments are mostly influenced by foggy weather.

Certain weather conditions, such as high or low temperatures can have the same effect on people from both urban and rural environments. So for example, the results of the research illustrate that during cold winter months when the temperature is low, blood pressure of the respondents' raises. These results confirm the opinions of different authors that wrote about increased blood pressure during winter months (Zuzelo, 2018). Authors such as Zheng have reached similar conclusions: that temperature changes can lead to illnesses (Zheng et al, 2016), or Bevan and Eckmann who have concluded that due to temperature drops, blood pressure changes (Bevan, 1987; Eckmann et al, 2000). High temperature affects the respondents' organisms, which was also confirmed by the author Kaiser in 2003, who states that high temperatures can cause exhaustion.

Furthermore, most respondents that had previously had some sort of fracture, state that they feel pain or discomfort in that area before it starts raining. The same effect is seen in patients with chronic illnesses that are taking therapy prescribed to them by a medical specialist. During rain or fog, when the respondents are not receiving therapy, their health significantly worsens. These results confirmed the fact that weather changes affect people with certain health issues (Horowitz, 2002; Živanović, 2015; Zheng et al, 2016).

The research also showed that most people from urban environments have problems with high blood pressure that has a detrimental effect on the heart. This verifies the data from the World Health Organization that stated that the deadliest illnesses in 2016 were heart diseases. 
Foggy weather accompanied with high air humidity has an effect on the respondents. These weather conditions mostly affect people from rural environments. The results of the research confirm the statements that the author Dukic made in 1967, about high air humidity causing difficulties in breathing even in healthy individuals.

The changes of certain meteorological elements can cause different problems in people that live in completely different environments. The research has shown that the mood of the respondents on rainy days was different, so the ones who live in urban environments thought of their mood as well, while their counterparts in rural environments thought of their mood as poor. Furthermore, most of the respondents in rural environments reported that they had headaches on rainy days. In urban environments, they stated that they sometimes have trouble with headaches. These results coincide with the ones that authors such as Brkic made, where he stated that the intensity of a person's reaction to weather changes is different, and also Zivanovic that spoke about how certain organisms respond to changes with more ease, while others are more sensitive to them (Brkić, 2006; Živanović, 2015).

Weather changes affect mood, rheumatic pains, headaches which authors such as Kaiser in 2003 and Zivanovic in 2015 have also observed. Kaiser states in his paper from 2003 that weather can affect the apparition of headaches and rheumatic pains, while Zivanovic includes mood changes, increased and decreased blood pressure and asthma attacks as well.

Atmospheric pressure also has an effect on the respondents. The majority of the respondents sometimes have health issues during atmospheric pressure changes. This validates the statement Dukic made in 1967, where he concluded that high atmospheric pressure could slow down breathing movements, while low atmospheric pressure can have a detrimental effect on patients with cardiac and rheumatic problems.

The research that was conducted on a sample of 130 respondents has verified the hypothesis set prior. The hypothesis: Weather changes in urban and rural environments have an influence on a person's health. Hypothesis number 1: The weather changes in urban and rural environments affect healthy people. Hypothesis number 2: The weather changes in urban and rural environments affect healthy people with certain diagnosis. Hypothesis number 3: Weather conditions and phenomena have a different effect on people in urban and rural environments. As an example, the changes in atmospheric pressure in most respondents from rural environments have no effect on their health. Furthermore, in rural environments people usually have headaches during rainy days, while the respondents from urban environments only have them occasionally.

\section{Conclusions}

Nowadays people are leading faster paced lives and neglecting their health. A large number of factors can influence if people have problems with their blood pressure, or respiratory issues, mood swings and similar issues. Weather change stands out as one of the most important factors which can often make completely healthy individuals feel unwell or even worsen the physical state of patients with chronic illnesses. 
Weather changes had different effects depending on the group that was tested. Some people can handle temperature changes or shifts in the atmospheric pressure, while others may have more difficulties with them. The results of the research have shown that changes of different meteorological states can influence both a healthy organism and the one that has chronic issues. Certain elements, such as high temperature fluctuations or high air humidity can have an impact on people in urban environments. The biggest effect on people in rural environments is fog weather. Research shows that headaches and poor mood in respondents are directly linked to rain. Moreover, high temperatures can exhaust a healthy organism. The effects of cold weather on blood pressure are also of great importance. The worst possible outcome of low temperature weather for people with elevated blood pressure is death. This is why it is crucial for a person to thoroughly prepare for weather changes by carrying out prescribed therapy or other alternative methods that can help reduce the effects of weather changes on health.

\section{Conflict of interests}

The authors declare no conflict of interest.

\section{References}

1. Andreoli, T. E., Loscalzo, J., Carpenter, C. C. J. and Griggs, R. C. (2008). CECIL Essentially in medicine. IKP Evro-Giunti, Belgrade. [in Serbian: Andreoli, T. E., Loscalzo, J., Carpenter, C. C. J., Griggs, R. C. (2008). CECIL Suštinsko u medicini].

2. Ballester, F., Michelozzi, P. And Iñiguez, C. (2003). Weather, climate, and public health. Journal of Epidemiology \& Community Health, BMJ Group, No. 57, pg. 759-760, London.

3. Bevan, Dž. (1987). Family doctor. First volume - glossary. Nolit, Belgrade. [in Serbian: Беван, Џ. (1987), Породични лекар. Први том - појмовник].

4. Brkić, B. (2006). The impact of climate on human health. Croatian Journal of Public Health, Vol.2, No. 8., Zagreb. Available at: http://hcjz.hr/index.php/hcjz/ article/view/2007/1983 Accessed on June 4th. 2018. [in Croatian: Brkić, B. (2006). Utjecaj klimatskih prilika na zdravlje čovjeka].

5. Čučalin, A. G. (1985). Bronchial asthma, Medicine, Moscow. [in Russian: Чучалин, А. Г. (1985), Бронхиальная астма].

6. Cvetanović, S. S., Đekić, M., Stožinić, S., Vojnović-Kljajić, R., Tramošljanin, M., Jovanović, O. and Hydrometeorological Institute of the Republic of Serbia. (1988), The Impact of Time on Human Health, Scientific Paper, Belgrade. [in Serbian: Цветановић, С. С., Ђекић, М., Стожинић, С., Војновић-Кљајић, Р., Трамошљанин, М., Јовановић, О., Хидрометеоролошки завод РС. (1988), Утицај времена на здравље људи].

7. Deljanić, I., (1976). Basics of meteorology. Hydrometeorological Technical School, Belgrade. [in Serbian: Дељанић, И., (1976). Основи метеорологије]. 
8. Dukić, D. (1967). Climatology with the basics of meteorology. Scientific book, Belgrade. [in Serbian: Дукић, Д. (1967). Климатологија са основама метеорологије].

9. Eckmann, D. M., Bowers, S., Stecker, M. and Cheung, A. T. (2000). Hematocrit, volume expander, temperature, and shear rate effects on blood viscosity. Anesthesia \& Analgesia, University of Pennsylvania, 91 (3),. Philadelphia.

10. Gajić, V. (2013). A historical overview of the study of the impact of time on humans and the development of medical meteorology. ABC Emergency Medicine Journal, Serbian Medical Association (Emergency Medicine Section), Vol. XIII, broj 2-3, 65-69., Belgrade. [in Serbian: Гајић, В. (2013). Историјски преглед проучаваға утицаја времена на људе и развој медицинске метеорологије].

11. Horowitz, S. (2002). Biometeorology: What it is and how it affects our health. Alternative \& Complementary Therapies, Mary Ann Liebert, 8 (11), pg. 34-39., New York.

12. Huber, M., Knottnerus, J.A., Green, L., van der Horst, H., Jadad, A.R., Kromhout, D. and Smid, H. (2011). How should we define health? British Medical Journal, The BMJ, BMA House, 343(7817), p. 235-237., London.

13. Kajzer, M. (2003). How weather affects health. Publishing house "Draganić", Novi Beograd. [in Serbian: Kajзep, M. (2003). Како време утиче на здравље].

14. Kukutanov, G.R. (2014). Meteorology. Goce Delcev University, Štip. [in Macedonian: Кукутанов, Г.Р. (2014). Метеорологија].

15. Neves, G. Z. D. F., Gallardo, N. P. and Vecchia, F. A. D. S. (2017). A Short Critical History on the Development of Meteorology and Climatology. Climate, MDPI, 5 (1), 23., Basel, Switzerland.

16. Otoperec, S. (1991). Agrometeorology. Scientific book, Belgrade. [in Serbian: Оторепец, С. (1991), Агрометеорологија].

17. Putniković, M.S. (2017). Objective classification of atmospheric circulation above Serbia - doctoral dissertation, University of Belgrade, Faculty of Physics, Belgrade. [in Serbian: Путниковић, М.С. (2017), Објективна класификација атмосферске ичиркулаиије изнад Србије- докторска дисертација].

18. Sacks, F. M., Svetkey, L. P., Vollmer, W. M., Appel, L. J., Bray, G. A., Harsha, D. and Karanja, N. (2001). Effects on blood pressure of reduced dietary sodium and the Dietary Approaches to Stop Hypertension (DASH) diet, New England journal of medicine, NEJM Group, 344 (1), 3-10., Boston MA.

19. Todorović, B. (2012). Aeronautical meteorology. Ultralight pilot school "MAGplastic", Smederevo. [in Serbian: Тодоровић Б., (2012), Ваздухопловна метеорологија].

20. Vujević, P. (1948). Meteorology. Prosveta-publishing company of Serbia, Belgrade. [in Serbian: Вујевић, П. (1948). Метеорологија]. 
21. World Health Organization, Available at: http://www.who.int/news-room/factsheets/detail/the-top-10-causes-of-death Accessed on: June 1st 2018.

22. Zheng, S., Wang, M., Li, B., Wang, S., He, S., Yin, L. and Li, T., (2016). Gender, age and season as modifiers of the effects of diurnal temperature range on emergency room admissions for cause-specific cardiovascular disease among the elderly in Beijing. International journal of environmental research and public health, MDPI, 13(5), 447., Basel, Switzerland.

23. Živanović, S. (2015). Forms and trends of health tourism. Faculty of Hospitality and Tourism, Vrnjačka Banja. [in Serbian: Живановић C., (2015), Облиции и трендови здравственог туризма].

24. Živanović, S. and Manojlović, N. (2016). Human biometeorology with biothrop weather conditions and meteorotropism in the context od health tourism, The First International Scientific Conference: Tourism in function of development of the Republic of Serbia, 2-4 June, Vrnjačka Banja, University of Kragujevac, Faculty of Hotel Management and Tourism, p.20-35. Vrnjačka Banja. Available at: http://www.hit-vb.kg.ac.rs/conference/images/thematic proceedings/thematicproceedings-i.pdf Accessed on: April 7th 2018.

25. Zuzelo, P. R. (2018). The Interconnectedness of Climate, Weather, and Living Organisms' Health. Holistic nursing practice, LWW Business Offices, 32(1), 5658., Philadelphia 